\title{
Role of Human Genome Project in Medical Science
}

\author{
Muhammad Arif Saleem, Ayesha Aslam \& Mahwish Sajid Ahreen \\ Institute of Molecular Biology \& Biotechnology, Bahauddin Zakariya University, Multan - 60800, Pakistan.
}

DOI: $10.38177 / A J A S T .2020 .4202$

\section{ABSTRACT}

Human Genome Project is a worldwide scientific achievement. It was a thirteen-year project initiated in 1990 and completed in 2003 . Human Genome Project helped a lot in the identification of diseased genes as DNA is very significant for understanding the diseased gene and their functions. It helped in the identification of disease loci for many diseases and presented their treatment through preventive measures. It identified the gene loci for many diseases like cancer, asthma, high blood pressure, diabetes type 2, obesity, Alzheimer's disease, Down's syndrome, Turner's syndrome, depression and many types of heart diseases including cardiovascular disease and coronary artery disease. This project does not directly treat the diseases but it helps in the identification of disease gene loci and then allows the treatment of disease through its preventive measures before the appearance of symptoms or at the initial stages of the disease through many techniques like gene therapy, pharmacogenomics, and targeted drug therapy. These are the helpful techniques in the diagnoses of the human disease gene locus.

\section{Introduction}

Human Genome Project is a worldwide collaborative biological project initiated in 1990 by the Department of Energy collaboration with the National Institutes of Health to sequence three billion nucleotide bases of 80,000 estimated genes of Human Genome. Up till now, Whole Genome Sequence is considered as an encoding of the blueprint of life but the function of nearly 3 billion nucleotide bases is still unknown (Elements, 2012).

Human Genome Project helped a lot in the identification of diseased genes as DNA is very significant for understanding diseased genes and their functions. Except for some cases of trauma, every human disease has some genetic component. The large-scale genome research has driven the technology advancement in genetic testing, drug design, gene therapy, and other genetic related areas such as pharmacogenetics (Innovation \& Wattanapitayakul, 2016).

This project does not directly treat the diseases but it helps in the identification of disease gene loci and then allows the treatment of disease through its preventive measures before the appearance of symptoms or at the initial stages of the disease through many techniques like gene therapy, pharmacogenomics, and targeted drug therapy (Collins \& Mckusick, 2001).

\begin{tabular}{|c|l|l|l|l|}
\hline Disease Names & $\begin{array}{l}\text { Locus identified } \\
\text { for the disease }\end{array}$ & $\begin{array}{l}\text { Techniques used } \\
\text { for the } \\
\text { identification }\end{array}$ & $\begin{array}{c}\text { Findings of the } \\
\text { author }\end{array}$ & \multicolumn{1}{|c|}{ Citations } \\
\hline Asthma & $\begin{array}{l}\text { A locus on } \\
\text { chromosome } \\
17 \mathrm{q} 12-21\end{array}$ & $\begin{array}{l}\text { single nucleotide } \\
\text { polymorphisms } \\
\text { (SNPs) }\end{array}$ & $\begin{array}{l}\text { The strongest } \\
\text { evidence was found }\end{array}$ & (Wan et al., 2012) \\
\hline Diabetes type 2 & Locus on 12q15 & $\begin{array}{l}\text { Microsatellite } \\
\text { markers }\end{array}$ & $\begin{array}{l}\text { The strongest } \\
\text { evidence was found } \\
\text { for this disease on } \\
\text { chromosome 12q15 }\end{array}$ & $\begin{array}{l}\text { (Bektas, Hughes, } \\
\text { Warram, } \\
\text { Krolewski, \& } \\
\text { Doria, 2001) }\end{array}$ \\
\hline
\end{tabular}




\begin{tabular}{|c|c|c|c|c|}
\hline Depression & $\begin{array}{l}\text { locus in the human } \\
\text { IL6 promoter }\end{array}$ & $\begin{array}{l}\text { Single nucleotide } \\
\text { polymorphism } \\
\text { (SNP) }\end{array}$ & & (Cole et al., 2010) \\
\hline Cancer & $\begin{array}{l}\text { Locus identified } \\
\text { between } \\
\text { chromosome } 9 \text { and } \\
12\end{array}$ & DNA sequencing & $\begin{array}{l}\text { Mutated- cancer } \\
\text { genes were } \\
\text { identified }\end{array}$ & $\begin{array}{l}\text { Stratton, } \\
\text { Campbell, \& } \\
\text { Futreal, 2009) }\end{array}$ \\
\hline $\begin{array}{c}\text { Cardiovascular } \\
\text { Disease }\end{array}$ & Chromosome 9p21 & $\begin{array}{l}\text { Single nucleotide } \\
\text { polymorphism } \\
\text { (SNP) }\end{array}$ & $\begin{array}{l}\text { Association of } \\
\text { chromosome locus } \\
9 \mathrm{p} 21 \text { with coronary } \\
\text { heart disease } \\
\text { (CAD) and } \\
\text { myocardial } \\
\text { infection (MI) and } \\
\text { represents the most } \\
\text { replicated locus. }\end{array}$ & (Disease, 2007) \\
\hline Hypertension & $\begin{array}{l}\text { A locus on } \\
\text { chromosome } 17\end{array}$ & $\begin{array}{l}\text { Solar software was } \\
\text { used }\end{array}$ & $\begin{array}{l}\text { The strongest } \\
\text { evidence was found } \\
\text { on chromosome } 17 \\
\text { for systolic B.p. and } \\
\text { for diastolic B.P. on } \\
\text { chromosome } 17 \text { and } \\
18 \text {. }\end{array}$ & (Levy et al., 2000) \\
\hline Obesity & $\begin{array}{l}\text { Gene locus was } \\
\text { identified on TNF } \\
\text { (Tumor necrosis } \\
\text { factor) on alpha } \\
\text { gene }\end{array}$ & $\begin{array}{l}\text { Gender-pooled } \\
\text { quantitative } \\
\text { sib-pair analysis }\end{array}$ & $\begin{array}{l}\text { A remarkable effect } \\
\text { of the gene locus on } \\
3 \text { global and } 7 \\
\text { regional measures } \\
\text { of obesity }\end{array}$ & $\begin{array}{l}\text { (Pausova et al., } \\
2000 \text { ) }\end{array}$ \\
\hline $\begin{array}{l}\text { Alzheimer's } \\
\text { disease }\end{array}$ & $\begin{array}{l}\text { The locus on } \\
\text { chromosome } 14\end{array}$ & $\begin{array}{l}\text { Markers assisted } \\
\text { technology }\end{array}$ & $\begin{array}{l}\text { The strongest } \\
\text { evidence was found } \\
\text { for Alzheimer's } \\
\text { disease on } \\
\text { chromosome } 14\end{array}$ & $\begin{array}{l}\text { (Schellenberg et } \\
\text { al., 2019) }\end{array}$ \\
\hline Down`s syndrome & $\begin{array}{l}\text { Due to the } \\
\text { presence of an } \\
\text { extra chromosome } \\
21\end{array}$ & $\begin{array}{l}\text { Southern blotting } \\
\text { and FISH } \\
\text { (fluorescent in-situ } \\
\text { hybridization) was } \\
\text { used }\end{array}$ & $\begin{array}{l}\text { Strong evidence } \\
\text { was found for the } \\
\text { locus present on } \\
\text { chromosome } 21 \text { for } \\
\text { Down's syndrome }\end{array}$ & $\begin{array}{l}\text { (Daumer et al., } \\
\text { n.d.) }\end{array}$ \\
\hline Turner`s syndrome & $\begin{array}{l}\text { X-linked } \\
\text { chromosome (45X, } \\
46 \mathrm{X}) .\end{array}$ & $\begin{array}{l}\text { Cytogenetic } \\
\text { analysis was } \\
\text { performed }\end{array}$ & $\begin{array}{l}\text { Neuropsychological } \\
\text { effects indicated } \\
\text { that short arm of } \\
\text { chromosome } 46 \mathrm{X} \\
\text { was missing in the } \\
\text { Turner's patient. }\end{array}$ & $\begin{array}{l}\text { (Skuse, Creswell, } \\
\& \text { Mcgurk, 1997) }\end{array}$ \\
\hline
\end{tabular}

\section{Conclusion}

Human Genome Project is a worldwide scientific achievement. It was a thirteen-year project initiated in 1990 and was completed in 2003. Human Genome Project helped a lot in the identification of diseased genes as DNA is very 
important for understanding diseased genes and their functions. It helped in the identification of disease loci for many diseases and presented their treatment through preventive measures. It identified the gene loci for many diseases like cancer, asthma, high blood pressure, diabetes type 2, obesity, Alzheimer's disease, depression and many types of heart diseases. This project does not directly treat the diseases but it helps in the identification of disease gene loci and then allows the treatment of disease through its preventive measures before the appearance of symptoms or at the initial stages of the disease through many techniques like gene therapy, pharmacogenomics, and targeted drug therapy.

\section{Acknowledgments}

We thank Dr. Muhammad Baber, Dr. Ghulam Shabbir and members of the Institute of Molecular Biology and Biotechnology (IMBB), Bahauddin Zakariya University, Multan Pakistan for helpful discussion.

\section{Conflict of Interest}

There is no conflict of Interest.

\section{Funding}

No source of funding is reported by the author.

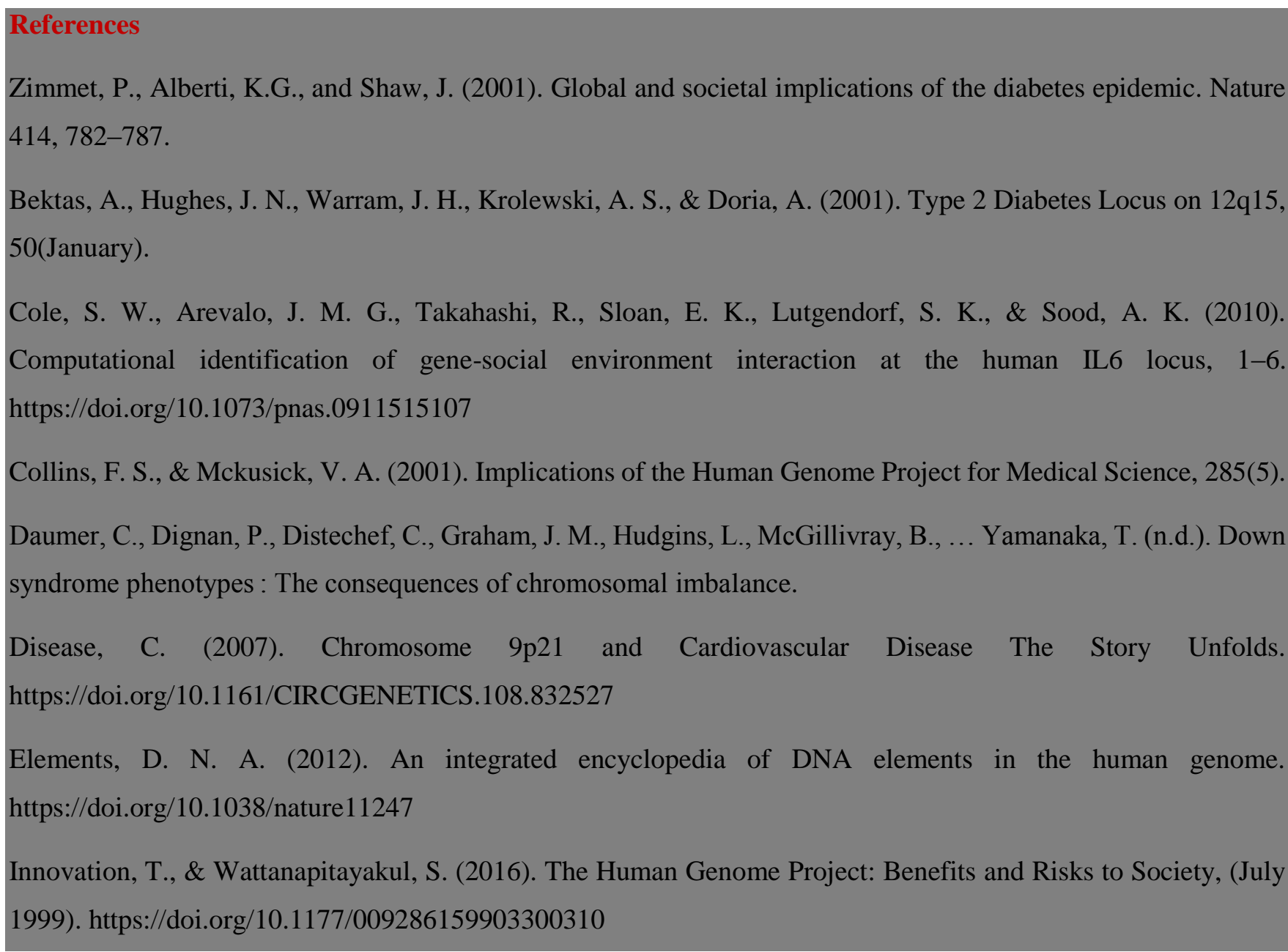


Levy, D., Destefano, A. L., Larson, M. G., Donnell, C. J. O., Richard, P., Gavras, H., ... Myers, R. H. (2000). Evidence for a Gene Influencing Blood Pressure. https://doi.org/10.1161/01.HYP.36.4.477

Martinez, F. D. (2003). Respiratory syncytial virus bronchiolitis and the pathogenesis of childhood asthma, 22(2), $76-82$.

P, S. V., \& Elizabeth, M. (2004). Turner's Syndrome, 1227-1238.

Pausova, Z., Deslauriers, B., Gaudet, D., Tremblay, J., Kitchen, T. A., Larochelle, P., ... Hamet, P. (2000). Role of Tumor Necrosis Factor- $\smile$ Gene Locus in Obesity and Obesity-Associated Hypertension in French Canadians, 14-19. https://doi.org/10.1161/01.HYP.36.1.14

Schellenberg, G. D., Bird, T. D., Wijsman, E. M., Orr, H. T., Anderson, L., Nemens, E., .. Martin, G. M. (2019). Genetic Linkage Evidence for a Familial Alzheimer 's Disease Locus on Chromosome 14 Published by American Association for the Advancement of Science Stable URL : https://www.jstor.org/stable/2880204 digitizes, preserve and extend access to Science Genetic Linkage Evidence for a Familial Alzheimer ' s Disease Locus on Chromosome 14, 258(5082), 668-671.

Skuse, D. H., Creswell, C., \& Mcgurk, R. (1997). Evidence from Turner's syndrome of an imprinted X-linked locus affecting cognitive function, 387(June), 705-708.

Stratton, M. R., Campbell, P. J., \& Futreal, P. A. (2009). The cancer genome. Nature, 458(7239), 719-724. https://doi.org/10.1038/nature07943

Wan, Y. I., Shrine, N. R. G., Artigas, M. S., Wain, L. V, Blakey, J. D., Moffatt, M. F., ... Hall, I. P. (2012). Genome-wide association study to identify genetic determinants of severe asthma. https://doi.org/10.1136/thoraxjnl-2011-201262

Martin, B.C., Warram, J.H., Krolewski, A.S., Bergman, R.N., Soeldner, J.S., and Kahn, C.R. (1992). Role of glucose and insulin resistance in the development of type 2 diabetes mellitus: results of a 25 -year follow-up study. Lancet 340, 925-929.

Weyer, C., Bogardus, C., Mott, D.M., and Pratley, R.E. (1999). The natural history of insulin secretory dysfunction and insulin resistance in the pathogenesis of type 2 diabetes mellitus. J. Clin. Invest. 104, 787-794.

DeFronzo, R.A., Bonadonna, R.C., and Ferrannini, E. (1992). Pathogenesis of NIDDM. A balanced overview. Diabetes Care 15, 318-368.

Clark, A., Wells, C.A., Buley, I.D., Cruickshank, J.K., Vanhegan, R.I., Matthews, D.R., Cooper, G.J., Holman, R.R., and Turner, R.C. (1988). Islet amyloid increased A-cells, reduced B-cells and exocrine fibrosis: quantitative changes in the pancreas in type 2 diabetes. Diabetes Res. 9, 151-159.

Porte, D.J., and Kahn, S.E. (2001). beta-cell dysfunction and failure in type 2 diabetes: potential mechanisms. Diabetes 50 (Suppl. 1),S160-S163. 
Gerich, J.E. (1998). The genetic basis of Type 2 diabetes mellitus: impaired insulin secretion versus impaired insulin sensitivity. Endocr. Rev. 19, 491-503.

Gumbiner, B., Van Cauter, E., Beltz, W.F., Ditzler, T.M., Griver, K., Polonsky, K.S., and Henry, R.R. (1996). Abnormalities of insulin pulsatility and glucose oscillations during meals in obese noninsulin-dependent diabetic patients: effects of weight reduction. J. Clin.Endocrinol. Metab. 81, 2061-2068.

Del Prato, S., Marchetti, P., and Bonadonna, R.C. (2002). Phasic insulin release and metabolic regulation in type 2 diabetes. Diabetes 51 (Suppl. 1), S109-S116.

Butler, A.E., Janson, J., Bonner-Weir, S., Ritzel, R., Rizza, R.A., and Butler, P.C. (2003). Beta-cell deficit and increased beta-cell apoptosis in humans with type 2 diabetes. Diabetes 52, 102-110.

Bruning, J.C., Winnay, J., Bonner-Weir, S., Taylor, S.I., Accili, D., and Kahn, C.R. (1997). Development of a novel polygenic model of NIDDM in mice heterozygous for IR and IRS-1 null alleles. Cell 88,561-572.

Lauro, D., Kido, Y., Castle, A.L., Zarnowski, M.J., Hayashi, H., Ebina, Y., and Accili, D. (1998). Impaired glucose tolerance in mice with a targeted impairment of insulin action in muscle and adipose tissue.Nat. Genet. 20, 294-298.

Nandi, A., Kitamura, Y., Kahn, C.R., and Accili, D. (2004). Mouse models of insulin resistance. Physiol. Rev. 84, $623-647$.

Petersen, K.F., Dufour, S., Befroy, D., Garcia, R., and Shulman, G.I.(2004). Impaired mitochondrial activity in the insulin-resistant offspring of patients with type 2 diabetes. N. Engl. J. Med. 350, 664-671.

Sreekumar, R., Halvatsiotis, P., Schimke, J.C., and Nair, K.S. (2002).Gene expression profile in skeletal muscle of type 2 diabetes and the effect of insulin treatment. Diabetes 51, 1913-1920.

Mauvais-Jarvis, F., and Kahn, C.R. (2000). Understanding the pathogenesis and treatment of insulin resistance and type 2 diabetes mellitus: what can we learn from transgenic and knockout mice? Diabetes Metab. 26, 433-448.

McCarthy, M.I., and Froguel, P. (2002). Genetic approaches to the molecular understanding of type 2 diabetes. Am. J. Physiol. Endocrinol. Metab. 283, E217-E225. 